\title{
EFEKTIVITAS LATIHAN ROM DAN BOLA KARET TERHADAP PENINGKATAN KEKUATAN MENGGENGGAM DAN FUNGSI MENGGENGGAM PADA PASIEN STROKE DI RSUD SLEMAN
}

\section{EFFECTIVENESS ROM EXERCISE AND RUBBER BALL MOVEMENT AGAINST MUSCLE STRENGTH GRASPING AND HOLDING FUNCTION IN STROKE PATIENTS IN RSUD SLEMAN}

\author{
Ardin S Hentu ${ }^{*}$, Erna Rochmawati ${ }^{2}$, Erfin Firmawati ${ }^{3}$ \\ *1Program Pascasarjana Universitas Muhammadiyah Yogyakarta, Jl. Brawijaya, Kasihan, Tamantirto, \\ Kasihan, Bantul, Daerah Istimewah Yogyakarta, Email: ardinhentu@gmail.com, Indonesia \\ 2Universitas Muhammadiyah Yogyakarta Program Pascasarjana, Jalan Brawijaya, Kasihan, Tamantirto, \\ Kasihan, Bantul, Daerah Istimewah Yogyakarta, Indonesia \\ 3Universitas Muhammadiyah Yogyakarta Program Pascasarjana, Jalan Brawijaya, Kasihan, Tamantirto, \\ Kasihan, Bantul, Daerah Istimewah Yogyakarta, Indonesia
}

\begin{abstract}
Background: Stroke is the third leading cause of death after coronary heart disease and cancer. In stroke patients the main problem that will arise is the damage / death of brain tissue. Signs of the occurrence of damage to brain tissue is paralysis. Range of Motion and Rubber Ball Exercises are Rehabilitation that can be given. This exercise can tone the acupuncture points of the hands that indirectly signal to the sensory part of the nerve to be delivered to the brain.

Objective: To know the increase in grasping power and grasping functions in stroke patients after Range of Motion and rubber ball motion exercises.

Methods: The design used in this study is experimental quasy, using a control group. This research was conducted in RSUD Sleman. The sample in this study were 26 respondents divided into two groups. Sampling using purposive sample technique.

Result : The results of this study indicate an increase in the value of grasping muscle strength and grasping functions in Range of Motion and Rubber ball exercise.

Conclusion : Range of Motion exercises and rubber ball movement are effective in improving the value of muscle strength grasping and grasping functions. In expecting further research can increase the number of respondents.
\end{abstract}

Keyword : Grasping Power, Grasping Function, Range of Motion, Rubbing Ball, Stroke.

\section{PENDAHULUAN}

Stroke adalah sindrom klinis dengan gejala gangguan fungsi pada otak fokal atau global dengan tanda dan gejala yang terjadi selama 24 jam atau lebih, Stroke disebabkan adanya gangguan aliran darah dalam otak yang dapat timbul secara mendadak (dalam beberapa detik) atau secara cepat (dalam beberapa jam) dengan gejala atau tanda yang sesuai dengan daerah yang terganggu sebagai hasil dari infark cerebri (stroke iskemik). ${ }^{1}$

Efektivitas Latihan ROM dan Bola Karet Terhadap Peningkatan Kekuatan Menggenggam dan Fungsi Menggenggam pada Pasien Stroke di RSUD Sleman

Ardin S Hentu, Erna Rochmawati, Erfin Firmawati

MIK P-ISSN 2252-3413, E-ISSN 2548-6268
Stroke merupakan penyebab kematian peringkat ketiga setelah penyakit jantung koroner dan kanker sebagai penyakit mematikan di dunia, tercatat satu dari sepuluh kematian di dunia di alami oleh penderita stroke. ${ }^{2}$ Data dari Yayasan Stroke Indonesia menunjukkan bahwa Indonesia adalah urutan pertama dengan penderita stroke terbanyak di Asia Tenggara. ${ }^{3}$ 
Pada penderita stroke masalah utama yang akan timbul yaitu rusaknya/matinya jaringan otak yang dapat mengakibatkan berkurangnya atau bahkan hilangnya fungsi jaringan tersebut. ${ }^{4}$ Salah satu tanda terjadinya rusaknya jaringan otak yaitu adanya kecacatan berupa kelumpuhan anggota gerak hemiparesis, gangguan berpikir, berkurangnya daya ingat, menurunnya kemampuan bicara serta gangguan fungsi lainnya. ${ }^{5}$

Rehabilitasi merupakan program terapi dasar dari pemulihan pasien stroke yang Rehabilitasi yang dapat meningkatkan kemampuan pada penderita stroke yang mengalami kelemahan dapat diberikan berupa latihan fisik. Latihan ini dapat kali dalam seminggu dengan durasi 1 jam pada setiap latihannya. ${ }^{6}$

Rehabilisasi pasca stroke salah satunya yaitu melalui latihan $R O M$ baik pasif ataupun aktif. Latihan $R O M$ ini ialah latihan yang dilakukan guna memaksimalkan dan mengoptimalkan fungsi dari persendian dari kemampuan seseorang yang tidak menimbulkan rasa nyeri. ${ }^{4}$ Range Of Motion (ROM) sendiri dapat di kombinasikan dengan tambahan sarana bola karet sebagai intervensinya.

Penggunaan bola pada latihan ini adalah yang memiliki ciri fisik bergerigi dengan sifat lembut/elastis. Penggunaan bola dengan ciri fisik tersebut diharapkan dapat mengalami gangguan fungsi gerak. $^{4}$ diberikan selama 4 minggu dengan latihan 2

menstilmulus titik akupuntur terutama pada bagian tangan yang secara tidak langsung akan memberikan sinyal ke bagian saraf sensorik pada permukaan tangan yang akan disampaikan ke otak. ${ }^{7}$

Latihan menggengam bola ini juga dapat merangsang serat-serat otot untuk berkontraksi, hanya dengan sedikit kontraksi kuat setiap latihan dengan karakteristik bola karet yang memilikiki tekstur bergerigi dan lentur akan melatih reseptor sensorik dan motorik. $^{8}$

Beberapa penelitian telah dilakukan sebelumnya salah satunya penelitian yang dilakukan oleh Beebe \& Lang menunjukkan peningkatan yang signifikan pada pemberian ROM secara rutin, dimana peningkatan kekuatan otot yang sebelum pemberian ROM skalanya 2 dan setelah pemberian ROM meningkat menjadi $3{ }^{9}$

Pemulihan fungsi ektremitas atas biasanya terjadi dalam rentang waktu 4 minggu, latihan yang dapat dilakukan dalam meningkatkan fungsi ekstremitas atas yaitu menggenggam, mencengkram, bergerak, dan melepaskan beban. ${ }^{10}$

Berdasarkan hal tersebut peneliti tertarik menelititi tentang "Apakah latihan Range Of Motion (ROM) dan gerakan bola karet efektif meningkatkan kekuatan otot menggengam dan fungsi menggenggam pada pasien stroke di RSUD Sleman?".

\section{BAHAN DAN CARA PENELITIAN}

Jenis penelitian ini adalah penelitian kuantitatif dengan desain yang digunakan Efektivitas Latihan ROM dan Bola Karet Terhadap Peningkatan Kekuatan Menggenggam dan Fungsi Menggenggam pada Pasien Stroke di RSUD Sleman 
dalam penelitian ini menggunakan quasy experimental design with control group. Penelitian ini akan melihat apakah latihan Range Of Motion Dan gerakan Bola Karet dapat meningkatkan nilai kekuatan otot menggenggam dan fungsi menggenggam pada pasien stroke yang mengalami kelemahan hemiparesis. Jumlah pasien Stroke Di ruang Rehabilitasi Medik RSUD Sleman adalah sebesar 26 pasien.

Tehnik analisis data pada penelitian ini menggunakan Independent T-test pada data yang berdistriusi normal yaitu pada variabel kekuatan menggenggam, dan Mann Whitney pada data yang tidak berdistribusi normal yakni pada variabel fungsi menggengam. pengambilan sampel adalah dengan menggunakan tehnik Purposive Sample dimana sample pada penelitian ini ialah pasien dengan stroke hemoragi maupun hemiparesis dan yang memiliki kekuatan otot minimal 2, kemudian di bagi kedalam dua kelompok yaitu kelompok kontrol dan kelompok intervensi. Dimana kelompok Intervensi sebanyak 14 responden dan 12 responden pada kelompok kontrol. Latihan di berikan sebanyak 6 kali pada masing-masing kelompok di mana dalam 1 minggu mendapatkan 2 kali latihan. Perbedaan kedua kelompok terletak pada latihan yang diberikan yakni pada kelompok intervensi diberikan latihan ROM dan bola karet, sedangkan pada kelompok kontrol hanya diberikan latihan ROM saja. Bola karet yang digunakan pada pada penelitian ini yaitu bola karet yang pada permukaannya bergerigi dan lentur, latihan menggenggam bola karet diilakukan selama 10 hingga 15 menit.

\section{HASIL DAN PEMBAHASAN}

Dari pelaksanaan kegiatan yang telah dilakukan, berikut adalah hasil penelitian berupa karakteristik responden, nilai kekuatan otot dapat di lihat pada tabel berikut.

Tabel 1 Karakteristik responden $\quad(\mathrm{N}=26)$

\begin{tabular}{|c|c|c|c|c|}
\hline \multirow[t]{3}{*}{ Kategori } & \multicolumn{4}{|c|}{ Kelompok } \\
\hline & \multicolumn{2}{|c|}{ Intervensi } & \multicolumn{2}{|c|}{ Kontrol } \\
\hline & $F$ & $\begin{array}{c}\text { Total } \\
(\%)\end{array}$ & $\mathrm{F}$ & $\begin{array}{c}\text { Total } \\
(\%)\end{array}$ \\
\hline \multicolumn{5}{|l|}{ Usia } \\
\hline $50-54$ & - & - & 3 & 25 \\
\hline $55-59$ & 7 & 50 & 4 & 25 \\
\hline $60-64$ & 5 & 35,7 & 5 & 33 \\
\hline $65-69$ & 1 & 7,1 & - & - \\
\hline$>70$ & 1 & 7,1 & - & - \\
\hline \multicolumn{5}{|l|}{ R.Penyakit } \\
\hline Hipertensi & 8 & 57,1 & 8 & 60,2 \\
\hline Diabetes & 6 & 42,8 & 3 & 38,5 \\
\hline Jantung & - & - & 1 & 3,2 \\
\hline \multicolumn{5}{|l|}{$\begin{array}{l}\text { Serangan } \\
\text { stroke }\end{array}$} \\
\hline $\mathrm{Ke}-1$ & 10 & 71,4 & 8 & 66,7 \\
\hline$>1$ & 4 & 28,6 & 4 & 33,3 \\
\hline \multicolumn{5}{|l|}{ Pendidikan } \\
\hline Sd & 5 & 35,7 & 2 & 16,7 \\
\hline SMA & 6 & 42,9 & 8 & 66,7 \\
\hline Diploma & 2 & 14,3 & - & - \\
\hline Sarjana & 1 & 7,1 & 2 & 16,7 \\
\hline \multicolumn{5}{|l|}{$\begin{array}{l}\text { Jenis } \\
\text { Kelamin }\end{array}$} \\
\hline Laki-laki & 9 & 64,3 & 6 & 50 \\
\hline Perempuan & 5 & 35,7 & 6 & 50 \\
\hline
\end{tabular}

Berdasarkan tabel 1 didapatkan data bahwa pada karakteristik responden berdasarkan status umur khususnya pada kelompok intervensi hampir setengah responden memiliki umur 55-59 tahun. Sedangkan untuk kelompok kontrol terdapat 
empat responden yang memiliki umur 60-64 tahun dan untuk umur 50-54 serta 55-59 sebanyak 3 responden. Untuk riwayat penyakit terdapat 8 responden yang memiliki riwayat hipertensi untuk kedua kelompok, sedangkan diabetes terdapat 6 pada kelompok intervensi dan 3 responden pada kelompok kontrol untuk riwayat penyalit jantung terdapat 1 respnden yakni pada kelompok kontrol.

Karakteristik responden berdasarkan riwayat serangan stroke di dapatkan bahwa untuk kelompok intervensi terdapat 10 responden yang memiliki serangan ke 1, serta kelompok kontrol terdapat 8 responden. Untuk serangan ke 2 masing-masing kelompok terdapat 4 responden yang memiliki serangan stroke ke 2 .

Kelompok intervensi didapatkan data bawah tingkat pendidikan SD sebanyak 5 responden, SMA 6 responden, Diploma 2 responden, Sarjana 1 responden. Sedangkan untuk kelompok kontrol di dapatkan tingkat pendidikan SMA terbanyak yaitu sebanyak 8 responden, dan 2 responden pada tingkat pendidikan SD dan Sarjana. Jenis kelamin pria adalah yang memiliki responden terbanyak yaitu 9 responden untuk kelompok intervensi dan 6 untuk kelompok kontrol sedangkan untuk responden yang berjenis kelamin perempuan terdapat 5 responden pada kelompok intervensi dan 6 responden pada kelompok kontrol.
Tabel 2. Perbedaan Rata-Rata Nilai Kekuatan Otot Kelompok Intervensi Dengan Kelompok Kontrol Sebelum Dan Sesudah Perlakuan

\begin{tabular}{ccccc}
\hline Kelompok & $\mathrm{N}$ & $\mathrm{V}$ & Mean & P.value \\
\hline Intervensi & 14 & Pre & 2,07 & 0,008 \\
\cline { 2 - 4 } & 14 & Post & 2,57 & \\
\hline Kontrol & 12 & Pre & 2,00 & 0,048 \\
\cline { 2 - 4 } & 12 & Post & 2,33 & \\
\hline
\end{tabular}

Dari Tabel 2 menunjukkan nilai perbedaan kekuatan otot pada kelompok intervensi dan kelompok kontrol, dimana di dapatkan hasil nilai mean meningkat pada kelompok intervensi yaitu 2,57 dengan p.value 0,008 dan untuk kelompok kontrol di dapatkan mean 2,33 dengan p.value 0,048.

Tabel 3. Nilai Rata-Rata Pre dan Post Kekuatan Otot Pada Kelompok Intervensi dan Kelompok Kontrol

\begin{tabular}{lllll}
\hline $\begin{array}{l}\text { Kelom } \\
\text { pok }\end{array}$ & $\mathrm{N}$ & $\mathrm{V}$ & Mean & P.value \\
\cline { 1 - 4 } Pre & 14 & intervensi & 13,93 & 0,355 \\
\cline { 2 - 4 } & 12 & Kontrol & 11,83 & \\
\hline Post & 14 & Intervensi & 14,93 & 0,023 \\
\cline { 2 - 4 } & 12 & Kontrol & 13,00 & \\
\hline
\end{tabular}

Nilai rata-rata Pre dan Post kekuatan otot dapat dilihat dari tabel 3. Di mana didapatkan hasil bahwa pada kelompok intervensi nilai mean rank meningkat menjadi 14,93 dan pada kelompok kontrol di dapatkan nilai mean rank sebesar 13,00

Responden terbanyak pada penelitian ini berusia 55-59 tahun yang masuk pada kategori lansia awal, berdasarkan kategori usia menurut Depkes. Hipertensi dan diabetes merupakan riwayat penyakit yang biasanya terkena pada penderita stroke. Di usia 50 tahun atau pada masa lansia awal terjadi penurunan pada arteri yakni menjadi lebih kaku dan kurang mampu merespon 
tekanan darah, hal inilah yang menyebabkan seseorang yang memiliki riwayat hipertensi serta diabetes yang memiliki umur pada lansia awal lebih rentan terkena stroke. ${ }^{11}$ Faktor usia, ras, genetik, dan jenis kelamin pada penderita stroke merupakan faktor yang tidak dapat di ubah. ${ }^{1}$ Penelitian dari Made juga menemukan bahwa usia 55-59 tahun adalah usia yang terbanyak yang mengalami stroke yaitu sebesar $76 \%{ }^{12}$

Serangan Stroke pertama merupakan serangan terbanyak pada hasil penelitian yang telah dilakukan, Perbedaan ini di sebabkan karena pada serangan stroke yang pertama terjadi perubahan fisik yang jelas dibandingkan dengan keadaan sebelum serangan, seperti adanya penurunan kesadaran, kelemahan atau kelumpuhan pada sebagian tubuh, selain itu hal yang menyebabkan serangan kedua jarang terjadi karena setelah serangan pertama terjadi, maka pasien pasca stroke berusaha mengontrol berbagai faktor risiko penyebab stroke. $^{13}$

Tingkat pendidikan pada pasien stroke lebih mengarah terhadap pengetahuan penyakit tersebut, penanggulangan, serta pengobatan yang akan dijalani, semakin tinggi tingkat pendidikan sesorang maka gaya hidup serta kehidupan yang dijalani lebih stabil dan lebih sehat dibandingkan dengan tingkat pendidikan rendah. ${ }^{14}$

Jenis kelamin pria adalah yang terbanyak pada penelitian ini yaitu sebanyak 9 responden pada kelompok intervensi dan 6 pada kelompok kontrol. Hasil penelitian dari Sukmaningrum juga menunjukkan bahwa jenis kelamin pria adalah responden terbanyak yaitu 11 responden dan 7 pada kempok kontrol. ${ }^{15}$ Jenis kelamin pria cenderung lebih tinggi untuk terkena stroke dibandingkan wanita, perbandiangan ini yaitu $3: 1$. Jenis kelamin pria juga sebagai penderita terbanyak dapat dilihat dari pola hidup, pria cenderung memiliki pola hidup yang tidak sehat dibandingkan wanita, sebagai contoh kebiasaan merokok dan pola makan yang tidak sehat lebih banyak dilakukan oleh pria dibandingkan oleh wanita. $^{16}$

\section{Nilai Rata-rata Kekuatan Otot Pada Kelompok Kontrol dan Kelompok Intervensi}

Pada hasil penelitian didapatkan peningkatan nilai kekuatan otot yakni dengan nilai mean naik menjadi 2,57. Hal ini membuktikan bahwa pemberian latihan ROM dan gerakan bola karet efektif dalam meningkatkan nilai kekuatan otot. Pemberian latihan ROM dan bola karet sendiri merupakan terapi yang dapat meningkatkan atau merangsang sensorik di tangan dan mengririmkan sinyal ke otak. ${ }^{17}$ Rangsang sensorik halus dan tekanan akan diolah dalam korteks sensorik yang selanjutnya impuls disalurkan dalam korteks motorik. Impuls yang terbentuk di neuron motorik kedua pada nuclei nervi kranialis dan kornu anterius medulla spinalis berjalan melewati radiks anterior, pleksus saraf (di region 
servikal dan lumbosakral), serta saraf perifer dalam perjalanannya ke otot-otot rangka. Impuls dihantarkan ke sel-sel otot melalui motor end plate taut neuromuskular kemudian akan terjadi gerakan otot pada ekstremitas atas. Mekanisme ini dinamakan feed- forward control sebagai respon terhadap rangsang tekanan dan sentuhan halus bola karet pada tangan. ${ }^{18}$

\section{Nilai Rata-rata Pre dan Post Kekuatan Otot}

Pada Kelompok Intervensi dan Kelompok Kontrol

Dari hasil penelitian didapatkan peningkatan nilai kekuatan otot setelah dilakukan latihan ROM dan gerakan bola karet, di mana didapatkan nilai mean meningkat menjadi 14,93 pada kelompok intervensi dan 13,00 pada kelompok kontrol. Hal ini sejalan dengan hasil penelitian yang dilakukan oleh Daya yang menunjukkan peningkatan nilai kekuatan otot pada pasien yang di berikan latihan ROM dan bola karet. 19

Peningkatan nilai kekuatan otot ini terjadi karena adanya latihan yang rutin dilakukan oleh responden yang dapat memberikan dampak pembesaran fibril otot. ${ }^{20}$ Maka dengan seringnya latihan pembesaran fibril otot juga semakin besar. Latihan menggenggam bola karet sendiri dapat membantu membagkitkan kembali kendali di otak serta latihan ini akan merangsang seratserat otot untuk lebih berkontraksi. ${ }^{21}$

\section{KESIMPULAN}

Latihan Range Of Motion dan gerakan bola karet terbukti efektif dalam meningkatkan kekuatan otot pada pasien stroke yang mengalami kelemahan gerak (Hemiparesis). Diharapkan pada penelitian selanjutnya dapat meningkatkan jumlah responden dan waktu pemberian terapi yang lebih banyak lagi.

\section{TERIMA KASIH}

1. dr. Joko Hastaryo, M.Kes, Direktur Rumah Sakit Umum Daerah Sleman

2. Ratih Pramudianingrum, S.Kep.,Ners Manager Pelayanan Pasien

3. dr. Hj. Sulistiwi, Sp.RM Penanggung Jawab Ruang Rehabilitasi medik RSUD Sleman

\section{KEPUSTAKAAN}

1. American Stroke Association \& American Heart Association. The Stroke Family Caregiver;2015

2. World Health Organization. Stroke forum; 2010

3. Yayasan Stroke Indonesia. Sekilas Tentang Stroke. www.yastroki.or.id/berita.php; 2011

4. Wiwit, S., Stroke \& Penanganannya. Jogjakarta; Katahati; 2010.

5. Valente, et al.. Ischemic Stroke Due to Middle Cerebral Artery M1 Segment Occlusion: Latvian Stroke Register Data. Proceedings of the Latvian Academy of Sciences. 2015; Volume 69, (5)

6. Staubli, P., Nef, T., Klamroth-marganska, V., \& Riener, R. Effects of intensive arm training with the rehabilitation robot ARMin II in chronic stroke patients: four single-cases, 10. https://doi.org/10.1186/1743-0003-6-46. 2009

7. Lumbantobing, SM. Stroke. Jakarta; Balai Penerbit FKUI; 2007 
8. Irfan, M.. Fisioterapi Bagi Insan Stroke. Edisi Pertama. Yogyakarta;Penerbit Graha IImu; 2010

9. Beebe, J. a., \& Lang, C. E. Active range of motion predicts upper extremity function 3 months after stroke. Stroke, 40(5), 1772-1779. https://doi.org/10.1161/STROKEAHA.108 $.536763 ; 2009$

10. Ghaziani, E., Couppé, C., Henkel, C., Siersma, V., Søndergaard, M., Christensen, H., \& Magnusson, S. P. Electrical somatosensory stimulation followed by motor training of the paretic upper limb in acute stroke: study protocol for a randomized controlled trial, 1-9. https://doi.org/10.1186/s13063-017$1815-9 ; 2017$

11. Kozier, B., Erb, G., Berman, A., Snyder, J.S. Fundamentals Of Nursing Concepts, Process, And Practice. Jakarta;EGC;2010

12. Made, N., Yunica, D., \& Ariana, P. A. Pengaruh Rom Exercise Bola Karet Terhadap Kekuatan Otot. Jurnal Keperawatan Buleleng ; 2016

13. Utomo, W. Tesis : Pengaruh Range of Motion (ROM) ekstremitas atas dengan menggunakan bola karet terhadap kekuatan otot pada pasien stroke di RSUPN DR. Cipto Mangunkusumo. Depok : Program Studi Pasca Sarjana FIK UI; 2008

14. Ming, S. W., Tsuo H. L., Chun, M.,Herng, C.C., \& Tzuo, Y. L. Sociodemographic and Health. Related Factors Associated with Cognitive impaliment in the elderly; Taiwan;BMC Public Health;2011

15. Sukmaningrum, F. Efektivitas Range Of Motion ( Rom ) Aktif-Asistif: Spherical Grip Terhadap Peningkatan Kekuatan Otot Ekstremitas Atas Pada Pasien Stroke, 14;2014

16. Pinzon, Rizaldy dan Asanti, Laksmi, Awas stroke! Pengertian, gejala, tindakan, perawatan dan pencegahan. Yogyakarta;Andi Offset;2010

17. Prok, W. Pengaruh latihan gerak aktif menggenggam bola pada pasien stroke diukur dengan handgrip dynamometer, 4 April 2016

18. I Gusti. Pengaruh latihan aktif menggenggam bola terhadap kekuatan

Efektivitas Latihan ROM dan Bola Karet Terhadap Peningkatan Kekuatan Menggenggam dan Fungsi Menggenggam pada Pasien Stroke di RSUD Sleman

Ardin S Hentu, Erna Rochmawati, Erfin Firmawati

MIK P-ISSN 2252-3413, E-ISSN 2548-6268 ekstremitas atas pada pasien stroke iskemia di BRSU tabanan. Available from: academia.edu; cited 22 sept 2015

19. Daya, A, D. Pengaruh Terapi Aktif Menggenggam Bola Karet Terhadap Kekuatan Otot Pada Pasien Stroke Non Hemoragik Di Wilayah Kerja Puskesmas Pengasih li Kulon Progo Yogyakarta; 2017

20. Saryono. Biokimia Otot. Yogyakarta ;Nuha Medika; 2011

21. Sulistiawan A \& Husna E. Pengaruh Terapi Aktif Menggenggam Bola Terhadap Kekuatan Otot Pasien Stroke Di RSSN Bukittinggi;2016 